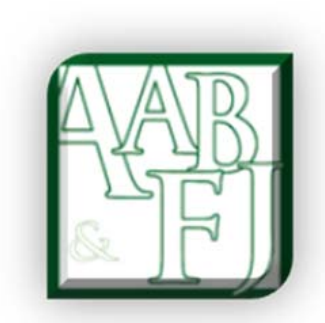

\title{
Behavioral Implications of Risk-Return Associations: An Application of Prospect Theory on CNX NIFTY Companies
}

\author{
Ranjan Dasgupta ${ }^{1}$
}

\begin{abstract}
This study primarily investigates the risk attitudes of the fifty CNX NIFTY companies from a behavioral perspective as proposed by Kahneman and Tversky (1979) and Tversky and Kahneman (1992). It hypothesizes that for below target returns, a large majority of Indian companies would be risk-seeking, and for above target returns, most of them would be riskaverse. To fulfil its objectives, this study uses rates of return on assets and equity and the capital ratios of fifty CNX NIFTY companies over the period 2009-2013. It also uses Kendall's (1938) test to measure the correlations between above variables within the relevant groups (all companies and each sub group [under Size and Industry]). Results show that bigger and smaller Indian companies and their managers are mostly risk-seeking and risk-averse respectively and shareholders-centric in regard to their attitude. These results will have important implications for the Indian companies and managers in evaluating their risk attitudes from the behavioral perspective.
\end{abstract}

JEL Classification: E37, F37, G12

Keywords: Risk-return, Prospect Theory, CNX NIFTY companies, ROA, ROE, Capital ratio, Behavioural, Behavioral, India

\footnotetext{
${ }^{1}$ Xavier University Bhubaneshwar, India
} 


\section{Introduction}

One of the most cited propositions in empirical finance literature is that expected risk and return have a positive relationship. Bowman (1980) for the first time contradicts this association by suggesting his famous 'risk-return paradox'. He advances his findings by pointing out "troubled companies take more risk" (Bowman, 1982). His findings were attributed to two factors. First of all, efficient corporate managers can increase return and reduce risk simultaneously. Thereby, the negative risk-return relationships occur. Second, these managers are not risk-averse rather they are risk-seekers. Thus, Bowman's $(1980 ; 1982)$ findings are critical to judge companies' risk-attitudes as they provide the basis of the well-known 'riskreturn paradox'. Overall, he suggests that risk-attitudes (i.e., risk-seeking or risk-averse) of the companies and their managers are well developed by the behavioral decision theories. It stresses the need and role of reference or target return level in the analysis of risky choices.

One of the most known behavioral representations is the Kahneman and Tversky's (1979) Prospect Theory which defines utility on a profit-loss basis by stating that the overall utility of a 'Prospect' is the expected utility of its 'outcomes'. Kahneman and Tversky's (1979) framework thus put the following testable hypotheses - when performance is below a given target return level, decision makers would be risk-seeking, and when performance is above that level, they would be risk-averse. It happens because high-variance (riskier) alternatives may provide a decision maker a better chance of achieving the desired outcome than low-variance (safer) alternatives. Though the Prospect Theory was initially developed at the individual decision maker's level, but since the 1980's, many scholars use it explicitly to analyze risk-return associations at the firm and industry levels, but mostly in the US.

This study investigates the presence of the Prospect Theory and Fishburn's (1977) measure of risk to explain variability of accounting measures in the CNX NIFTY companies. If variability of their returns is related to the extent to which they operate below target, such results would be consistent with the Prospect Theory and Fishburn's measure of risk [see Equation (1)]. In this endeavor, this study is based on the Johnson's (1994) framework. The contributions of this study are that it:

1. Concentrates on the CNX NIFTY companies over the period 2009 through 2013, a period of significant crises and after-crises changes in the Indian industries. The reason behind selection of CNX NIFTY is that it covers 23 sectors of the Indian economy and offers everyone the exposure to the Indian markets in one portfolio. Also, during 2008-12, CNX NIFTY Index's share of NSE market capitalization fell from $65 \%$ to $29 \%$ (SEBI, 2013).

2. Evaluates the associations between distance from target and variability of outcomes.

3. Investigates the question of an appropriate target return for the Indian companies as represented by the CNX NIFTY Index. and

4. Examines the Prospect Theory presence in light of the risk-return paradox for Industry (13 in total) and Size sub groups. 
This is also the first study on the Indian CNX NIFTY companies dealing with this topic and examining the behavioral implications of the Prospect Theory in terms of risk-attitudes (i.e., riskreturn associations) of them and their managers.

On April 22 $2^{\text {nd }}, 1996$, National Stock Exchange [NSE], India launched the new Equity Index 'The NSE-50' (better known as Nifty-50). CNX NIFTY is now a well diversified 50 stock Index accounting for 23 sectors of the economy with an aggregate market capitalization (MC) of around Rs.45,34,597 crores (as on March 31 ${ }^{\text {st }}$, 2014) (SEBI, 2014) from Rs.1,70,000 crores. It is used for a variety of purposes such as benchmarking fund portfolios, index based derivatives and index funds.

The rest of the paper is organized as follows - following introduction in Section 1, Section 2 introduces hypotheses and presents risk and return measurement, data descriptions, Size and Industry group classifications and test design. Section 3 presents the findings and required discussions of this study, followed by conclusion in Section 4 .

\section{Literature Review:}

Cheng (2010) overcome the shortcomings of Bowman's (1980) empirical study, as its conclusion cannot validate whether the result is biased due to the sampling period. The empirical findings of this study indicate that Chinese companies are more risk averse than Western companies to ensure earnings. However, Chinese companies are less sensitive than Western companies regarding risk-reward relationships. This is even more pronounced for well-performing Chinese companies based on market benchmarks, i.e., target levels or reference points. Brumagim and $\mathrm{Wu}$ (2005) conducted a questionnaire survey on Chinese companies regarding the management's attitude toward risks and found that Chinese management teams show a risk preference.

However, an increasing number of empirical results and theoretical arguments identified by Deephouse and Wiseman (2000) support Bowman's risk-return paradox with their empirical research on organizational behavior. Based on a literature review, Nickel and Rodriguez (2002) suggested that the level of risk preference on the part of management changes along with the environment. The same management may be risk-averse under some circumstances and may show risk neutrality, or even a risk appetite, under other circumstances. LaPorta et al. (2000) also indicated that corporate financial decisions are subject to the influence of external environments (e.g. laws and regulations, legal compliances, and cultures).

Fiegenbaum and Thomas (1988), in one of the earliest studies take a look at this Theory at the organizational level and explore the relationships between an organization's risks and return levels. They investigate the risk and return parameters of many industries using rate of Return on Equity (ROE) and variance of ROE as return and risk measures. Thus, they test Kahneman and Tversky's (1979) hypotheses by using accounting data, defining benchmark returns as median returns, and dividing their selected companies in two groups - above and below target returns. Their results strongly support the above presented Prospect Theory's implications. 
Jegers (1991) follows Fiegenbaum and Thomas's (1988) methodology to test some new return and risk variables like ROA (Return on Assets) in addition to ROE (which only reflects shareholders' viewpoint), which would also take into account the managerial performance view, and Cash Flow on Equity (CFE), and a Coefficient of Variation (CV) (defined as the standard deviation of returns divided by the average return), in addition to the variance of returns. Jegers (1991) calculates each firm's time average return, ranks firms according to these values and divides the firms into two equally sized groups - those with above and below target returns (the target is the median return). Then, Spearman rank correlations between risk and return and the negative association ratio are calculated for each group. The results corroborate with those of Fiegenbaum and Thomas's (1988). Miller and Leiblein (1996) favoured five-year average ROA as it does not vary with changes in financial leverage, as does ROE.

Finally, Johnson's (1994) analysis of risk-attitude in banks in a behavioral finance framework is also based on Fiegenbaum and Thomas (1988) and he uses Fishburn's (1977) measure of risk defined as dispersion about the mean outcome. Johnson (1994) tests several measures of return and risk for a sample of US commercial banks for the 1970-1989 periods. He uses standard measures of return like ROA and ROE, as well as Primary Capital Ratio (PCR). Risk is measured as standard deviation of outcome. The study aims at examining historical data to determine whether there is any evidence consistent with the Prospect Theory, by measuring the relationship between outcome variability and distance from target. Targets are also defined as the median values of return variables. Banks are classified in two separate groups according to this target, and correlation between distance to target and standard deviations are computed. The statistical tests are based on Kendall's (1938) $\tau$ correlation coefficient. The obtained results also support Fiegenbaum and Thomas's (1988) findings.

Alam and Boon Tang (2012) showed that Islamic banks located above target risk level tend to show risk-averse behaviour, while banks below target risk level inclined towards risk-seeking attitude. Their results also highlighted that banks which have higher loans to total asset ratio tend to take on lower risk. Kliger and Tsur (2011) also showed that firms with returns above their reference levels take less risk than firms with returns below their reference levels. However, Miller and Leiblein (1996) contradicted the idea that poor performers take on high variance strategies with low expected values. Using a fundamentally different concept of risk -downside risk, they indicated downside risk leads to organizational strategic changes that improve, rather than diminish, subsequent firm performance. Also, they found firms with exceptionally high performance avoid downside risk in the subsequent period.

Some scholars had also argued that the accuracy of accounting data or databases may influence the correctness of Bowman's risk-return paradox. Davis (1996) found that if survivorship bias is overlooked, explanatory variables based on accounting information will be over-estimated in the empirical results and explanatory power. Some literature sources come from Compustat Database and therefore have a survivorship bias problem for data before 1978. Chou et al. (2009) and Kliger and Tsur (2011) sampled data to correct the bias problem from Compustat Database, and their findings still support Bowman's (1980). 


\section{Research Methodology:}

\subsection{Hypotheses:}

Kahneman and Tversky's (1979) testable hypotheses imply that in a group of companies with above target returns, risk and return would be positively correlated, and for companies with below target returns, they would have negative correlations. However, in this regard Fiegenbaum and Thomas (1988: 90) highlight the misspecification bias implying that empirical analysis like this study can yield both positive and negative risk-return correlations in a situation that fits the Prospect Theory's assumptions.

However, the most important issue here is to identify a proper measure for the target returns level. Lev (1969: 290) emphasizes - "the desirability of adjusting the firm's financial ratios to predetermined targets which are usually based on industry wide averages." Frecka and Lee's (1983) also support Lev's (1969) viewpoint that companies should adjust financial ratios in a dynamic fashion to targets that appear to be industry-wide averages of those ratios. Kliger and Tsur (2011) calculated reference point annually based on past industrial performance. Jegers (1991) also defines the target level as the median return for the companies in an industry. So, as the objective of this study is to test the nature of the risk and return associations, this study uses the CNX NIFTY companies' median return.

Also, in line with the Prospect Theory suggestions and the results of the previous empirical studies, it tests the following two research hypotheses:

Hypothesis 1: A negative association between risk and return exists for CNX NIFTY companies below target return levels (i.e., CNX NIFTY companies' median returns).

Hypothesis 2: A positive association between risk and return exists for CNX NIFTY companies above target return levels (i.e., CNX NIFTY companies' median returns).

\subsection{Risk and Return Measurement:}

Fishburn (1977) further suggests that risk is not necessarily a measure of dispersion about an expected value, but rather a function of distance from a target outcome. He put this idea as follows:

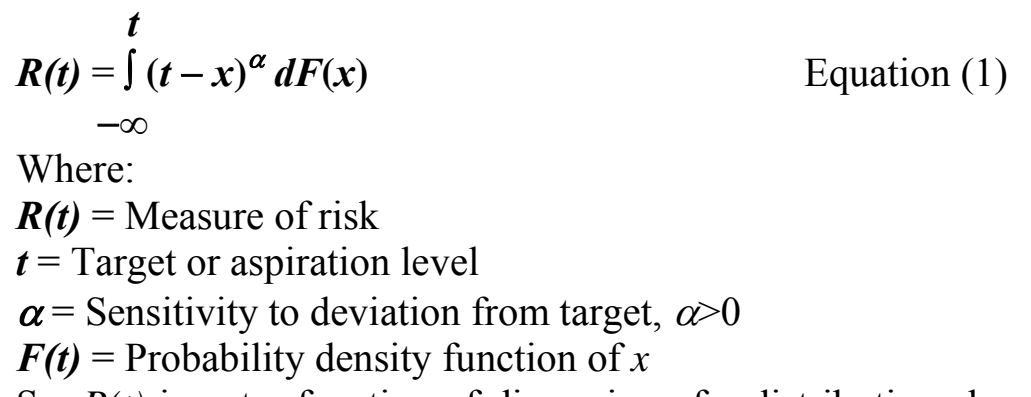

So, $R(t)$ is not a function of dispersion of a distribution about its mean, but is the likelihood of below-target outcomes. The positive parameter $\alpha$ measures companies' attitude toward this below-target results.

The decision making process in terms of risk-return of different industries is also investigated by many studies throughout the world. The rates of return on assets or equity (ROA/ROE) (see e.g., Blair and Heggestad, 1978; Hart and Jaffee, 1974; Koehn and Santomero, 1980; etc.) from the viewpoints of the managers and shareholders, and also Capital ratios (see e.g., Brewer and Lee, 
1986; and International Monetary Fund, 1990) from the perspectives of regulators and financial markets and their practitioners receive increasing attention in this regard. It is significant to note that all these three measures are interrelated as follows:

$\mathbf{R O A}=\mathbf{E} / \mathbf{T A} \times \mathbf{R O E} \quad$ Equation (2)

Where:

ROA $=$ Return on Assets (net income to total assets)

$\mathbf{E} / \mathbf{T A}=$ The Equity or Capital ratio (equity to total assets)

ROE $=$ Return on Equity (net income to equity)

Here, each of these is investigated as a possible target of the CNX NIFTY companies. Under this study, 'return' is measured as the average return (on assets and equity) over the study period, while 'risk' is operationalized as the standard deviation of returns over the same period. It also undertakes accounting data in line with past empirical studies (see e.g., Fiegenbaum and Thomas, 1988; Jegers, 1991; Johnson, 1994; etc.) for its investigation purpose because of its universal use among the managers, shareholders, regulators, competitors, etc.

\subsection{Data:}

This study has selected the period in between 2009-13 to avoid any significant and continual impact from the US sub-prime crisis which was originated in the US financial sector in July, 2007 (Dasgupta, 2013) and caused a serious collapse in international stock markets in January, 2008 (Gokay, 2009). However, over the crisis period as a whole (i.e., July 2007 to August 2009 [see Goldstein and Xie, 2011]), India has had the best performance (Goldstein and Xie, 2011). Although there were minor hiccups during 2008-09, but the overall economic growth of India stood at 5.3\% and 8.6\% (Bajpai, 2011) during the fiscal years of 2009-10 and 2010-11 respectively due to strong corporate performance. So, the crisis-impact on Indian corporate financial performance was not time-variant after the crisis.

This study obtains its required data from the annual reports of 50 CNX NIFTY companies and other internet resources, which are listed in this Index of the Indian stock markets for the undertaken study period. For each of them, the annual rates of return on assets and equity (ROA and $\mathrm{ROE}$ ) and the capital ratio (CR) are computed as follows:
$\mathbf{R O A}_{\text {in }}=\mathbf{N i}_{\text {in }} / \mathbf{T} \mathbf{A}_{\text {in }}$
Equation (3)
$\mathrm{ROE}_{\text {in }}=\mathrm{Ni}_{\text {in }} / \mathrm{E}_{\text {in }}$
Equation (4)
$\mathbf{C R}_{\text {in }}=\mathbf{E}_{\text {in }} / \mathrm{TA}_{\text {in }}$
Equation (5)

Where:

$\mathbf{R O A}_{\text {in }}=$ Rate of Return on Assets for companies $\mathrm{i}$ in year $\mathrm{n}$

$\mathbf{N i}_{\mathbf{i n}}=$ Net income for companies $i$ in year $n$

$\mathbf{T A}_{\text {in }}=$ Total assets for companies $\mathrm{i}$ in year $\mathrm{n}$

$\mathbf{R O E}_{\text {in }}=$ Rate of Return on Equity

$\mathbf{E}_{\text {in }}=$ Equity (i.e., book value) for companies $\mathrm{i}$ in year $\mathrm{n}$

$\mathbf{C R}_{\text {in }}=$ Capital ratio 


\subsection{Size and Industry Effects:}

Table 1.1: Industry breakdown of CNX NIFTY [i.e., Nifty-50] companies

\begin{tabular}{|l|l|l|}
\hline Nifty Classification & Classification under this Study \\
\hline Financial Services & Industry & Number of companies \\
\hline Information Technology (IT) & Automobiles \& Investment & 05 \\
\hline Energy & $\begin{array}{l}\text { Banking \& } \\
\text { Finance }\end{array}$ & 04 \\
\hline Consumer Goods & Cement & 03 \\
\hline Automobiles & Construction \& Infrastructure & 03 \\
\hline Pharmaceuticals & FMCG \& Food \& Beverages & 03 \\
\hline Construction & Information Technology (IT) & 05 \\
\hline Cement \& Cement Products & Metals & 03 \\
\hline Metals & Mining & 03 \\
\hline Telecom & Oil \& Gas & 05 \\
\hline Services & Paints & 01 \\
\hline Media \& Entertainment & Pharmaceuticals & 04 \\
\hline Industrial Manufacturing & Power & 03 \\
\cline { 2 - 3 } & Telecom & 01 \\
\hline
\end{tabular}

Table 1.2: Nifty-50 Companies and their Classifications

\begin{tabular}{|l|l|l|}
\hline Name of the Company & Nifty Classification & Classification under this Study \\
\hline ACC & Cement \& Cement Products & Cement \\
\hline Ambuja Cements Ltd. & Cement \& Cement Products & Cement \\
\hline Asian Paints Ltd. & Consumer Goods & Paints \\
\hline Axis Bank Ltd. & Financial Services & $\begin{array}{l}\text { Banking \& Investment } \\
\text { Finance }\end{array}$ \\
\hline Bajaj Auto Ltd. & Automobiles & Automobiles \\
\hline Bank of Baroda & Financial Services & $\begin{array}{l}\text { Banking \& Investment } \\
\text { Finance }\end{array}$ \\
\hline BHEL & Industrial Manufacturing & Construction \& Infrastructure \\
\hline BPCL & Energy & Oil \& Gas \\
\hline Bharti Airtel Ltd. & Telecom & Telecom \\
\hline Cairn India Ltd. & Energy & Oil \& Gas \\
\hline Cipla Ltd. & Pharmaceuticals & Pharmaceuticals \\
\hline Coal India Ltd. & Metals & Mining \\
\hline DLF Ltd. & Construction & Construction \& Infrastructure \\
\hline Dr. Reddy's Laboratories Ltd. & Pharmaceuticals & Pharmaceuticals \\
\hline Gail (India) Ltd. & Energy & Oil \& Gas \\
\hline Grasim Industries Ltd. & Cement \& Cement Products & Cement \\
\hline HCL Technologies Ltd. & IT & IT \\
\hline HDFC Bank Ltd. & Financial Services & $\begin{array}{l}\text { Banking \& Investment } \\
\text { Finance }\end{array}$ \\
\hline Hero Motocorp & Automobiles & Automobiles \\
\hline Hindalco Industries Ltd. & Metals & Metals \\
\hline & & \\
\hline
\end{tabular}




\begin{tabular}{|c|c|c|}
\hline HUL & Consumer Goods & FMCG \& Food \& Beverages \\
\hline HDFC & Financial Services & $\begin{array}{l}\text { Banking \& Investment } \\
\text { Finance }\end{array}$ \\
\hline ICICI Bank Ltd. & Financial Services & $\begin{array}{l}\text { Banking \& Investment } \\
\text { Finance }\end{array}$ \\
\hline IDFC & Financial Services & $\begin{array}{l}\text { Banking } \quad \& \quad \text { Investment } \\
\text { Finance }\end{array}$ \\
\hline ITC Ltd. & Consumer Goods & FMCG \& Food \& Beverages \\
\hline Indusind Bank Ltd. & Financial Services & $\begin{array}{l}\text { Banking \& Investment } \\
\text { Finance }\end{array}$ \\
\hline Infosys Ltd. & IT & IT \\
\hline Jindal Steel & Metals & Metals \\
\hline Kotak Mahindra Bank Ltd. & Financial Services & $\begin{array}{l}\text { Banking \& Investment } \\
\text { Finance }\end{array}$ \\
\hline L\&T Ltd. & Construction & Construction \& Infrastructure \\
\hline Lupin Ltd. & Pharmaceuticals & Pharmaceuticals \\
\hline M\&M Ltd. & Automobiles & Automobiles \\
\hline Maruti Suzuki India Ltd. & Automobiles & Automobiles \\
\hline Mcdowell-N/United Spirits & Consumer Goods & FMCG \& Food \& Beverages \\
\hline NMDC & Metals & Mining \\
\hline NTPC Ltd. & Energy & Power \\
\hline ONGC & Energy & Oil \& Gas \\
\hline Power Grid Corp. of India Ltd. & Energy & Power \\
\hline PNB & Financial Services & $\begin{array}{l}\text { Banking } \quad \& \quad \text { Investment } \\
\text { Finance }\end{array}$ \\
\hline RIL & Energy & Oil \& Gas \\
\hline Sesa-Sterlite & Metals & Mining \\
\hline SBI & Financial Services & $\begin{array}{l}\text { Banking \& Investment } \\
\text { Finance }\end{array}$ \\
\hline $\begin{array}{l}\text { Sun Pharmaceuticals Industries } \\
\text { Ltd. }\end{array}$ & Pharmaceuticals & Pharmaceuticals \\
\hline TCS & IT & IT \\
\hline Tata Motors Ltd. & Automobiles & Automobiles \\
\hline Tata Power Ltd. & Energy & Power \\
\hline Tata Steel Ltd. & Metals & Metals \\
\hline Tech Mahindra Ltd. & IT & IT \\
\hline Ultratech Cement Ltd. & Cement \& Cement Products & Cement \\
\hline Wipro & IT & IT \\
\hline
\end{tabular}


This study divides all the CNX NIFTY (i.e., Nifty-50) companies under 13 industries (see Table 1.1) which represent their respective sectors ${ }^{1}$. Some industries of similar nature are combined together under this study for research convenience. For example, the Financial Services and Consumer Goods (Nifty classifications) are represented by Banking \& Investment Finance and FMCG \& Foods \& Beverages respectively. Similarly, Cement \& Cement Products, Energy, and Construction and Industrial Manufacturing (Nifty classifications) are represented by Cement, Oil \& Gas and Power, and Construction \& Infrastructure respectively under this study. This study has also maintained some Nifty classifications like IT, Automobiles and Pharmaceuticals while added new classification like Paints for study purpose. Also, some Nifty classifications like Media \& Entertainment and Services don't have any representative in Nifty-50 Index. Table 1.1 provides the detailed classification data of these industries. Table 1.2 also provides the Nifty-50 companies during the study period and their respective Nifty and Study classifications.

Table 2.1: Nifty-50 Company Sizes

(based on Average Market Capitalization [in Rs. Billions])

\begin{tabular}{|l|l|l|l|l|}
\hline Rs. $0<250$ Billions & Rs. $250<500$ Billions & Rs.500<1,000 Billions & $\geq$ Rs. 1,000 Billions \\
\hline 33 & 7 & 4 & 6 \\
\hline Further Division of Rs. $0<250$ Billions Companies (33) \\
\hline Rs. $0<50$ Billions & $\begin{array}{l}\text { Rs. } 50<100 \\
\text { Billions }\end{array}$ & $\begin{array}{l}\text { Rs. } 100<150 \\
\text { Billions }\end{array}$ & $\begin{array}{l}\text { Rs. } 150<200 \\
\text { Billions }\end{array}$ & $\begin{array}{l}\text { Rs. } 200<250 \\
\text { Billions }\end{array}$ \\
\hline 0 & 8 & 8 & 8 & 9 \\
\hline
\end{tabular}

Table 2.2: Nifty-50 Company Weightages (in \%)

\begin{tabular}{|l|l|l|l|}
\hline $0 \%-<1 \%$ & $1 \%-<2.5 \%$ & $2.5 \%-<5 \%$ & $\geq 5 \%$ \\
\hline 20 & 19 & 5 & 6 \\
\hline
\end{tabular}

Note: Above $\%$ are taken looking at the representative weightages in the broad Nifty-50 Index.

Table 2.3: Nifty-50 Company Average Equity Share Capital (in Rs. Billions)

\begin{tabular}{|l|l|l|l|}
\hline Rs. $0<2.5$ Billion & Rs.2.5<5 Billions & Rs.5<10 Billions & $\geq$ Rs. 10 Billions \\
\hline 19 & 17 & 4 & 10 \\
\hline
\end{tabular}

Table 2.4: Size breakdown of CNX NIFTY [i.e., Nifty-50] companies

[Based on average Total Assets in Rs. \& \$ Millions (2009-13)]

\begin{tabular}{|l|l|l|l|}
\hline Size & $\begin{array}{l}\text { Amount } \\
\text { (in Rs. Millions) }\end{array}$ & $\begin{array}{l}\text { Amount } \\
\text { (in } \\
\text { Millions) }\end{array}$ & $\begin{array}{l}\text { Number of } \\
\text { Companies }\end{array}$ \\
\hline 1 & $0-2,50,000$ & $0-5,000$ & 17 \\
\hline 2 & $\begin{array}{l}2,50,001- \\
5,00,000\end{array}$ & $5,001-10,117$ & 11 \\
\hline 3 & $\begin{array}{l}5,00,001- \\
10,00,000\end{array}$ & $\begin{array}{l}10,118- \\
20,000\end{array}$ & 09 \\
\hline 4 & $\geq 10,00,001$ & $\geq 20,001$ & 13 \\
\hline
\end{tabular}

Company size may also affect risk and return patterns since peer group designations can often be based on size. Although the Nifty-50 companies are representing the large cap companies, but the average market capitalization of these companies during the study period (see Table 2.1) has 
pointed out that there are wide variations in regard to market-values of these companies. Also, the corresponding weightages of each of these companies in the broad Nifty-50 Index are also variable (see Table 2.2). This study has also considered the average equity share capital (issued and outstanding) during the study period (see Table 2.3). This is especially important as the $\mathrm{ROE}$ is one of the representatives of Indian companies' return under this study. All these information has evidenced that Nifty-50 companies do have size-variations and the Index is wellrepresented by different sized companies. So, testing of size effect is justified under this study. Thereby, the CNX NIFTY companies have been assigned a 'Size' variable from 1 to 4 under this study. The basis for these assignments is the average of total assets for the period tested (see Johnson, 1994). Table 2.4 provides the Size breakdown of these companies. However, Horowitz et al. (2000) found that the influence of size effects on the risk-return relationship has been gradually declining since the 1980 s.

\subsection{Test Design:}

This study relies on time average and their standard deviations measure and also their respective medians after the target returns level (i.e., industry's median return) is decided. It works with three zones:

Zone 1 - ROA, Zone 2 - ROE, and Zone 3 - CR

It also splits the sample in two areas for each zone- Above and Below, corresponding respectively to companies above and below the target level, i.e., the median of the variable corresponding to the zone, to incorporate the Fishburn's (1977) measure of risk.

The Prospect Theory and Fishburn's measure of risk suggest that decision makers are more willing to accept variability the further below target they find themselves. Thus, the standard deviation of outcome (i.e., returns) should be related to distance from target when decision makers are above or below target. It defines distance from target as follows:

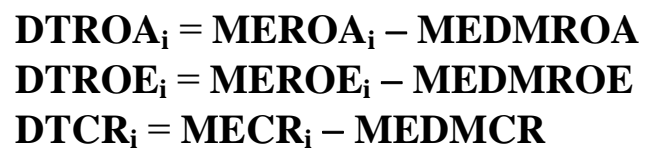

Where:

MEROA $_{\mathbf{i}}$, MEROE $_{\mathbf{i}}$ and $\mathbf{M E C R}_{\mathbf{i}}=$ Time series median ROA, ROE and CR respectively, for company i.

It also designates the Standard deviation of outcome (i.e., returns) by the following variables $\mathrm{SDROA}_{i}, \mathrm{SDROE}_{\mathrm{i}}$ and $\mathrm{SDCR}_{\mathrm{i}}$.

It uses Kendall's (1938) test here over and above other correlation tests as because the data is non-normal or ordinal and as there are outliers. Kendall's test is used to measure the correlations between these variables within the relevant groups (overall and Size and Industry sub groups). Kendall's possible values range from +1 (perfect positive correlation) to -1 (perfect negative correlation). However, if Kendall's value is consistently negative below target and positive above target, such results would tend to support the Fishburn's measure of risk and the Prospect Theory implications. 


\section{Results and Discussions:}

Table 3: Descriptive statistics

\begin{tabular}{|c|c|c|c|}
\hline \multicolumn{4}{|l|}{ A. Mean } \\
\hline & ROA & $\mathrm{ROE}$ & $\mathrm{CR}$ \\
\hline Overall & 10.71640 & 21.78228 & 1.47120 \\
\hline Size 1 & 16.66824 & 29.09059 & 1.54324 \\
\hline Size 2 & 12.13182 & 21.03655 & 1.56791 \\
\hline Size 3 & 6.56133 & 16.77556 & 1.91630 \\
\hline Size 4 & 4.61215 & 16.32246 & 0.98702 \\
\hline Automobiles & 14.77600 & 31.67200 & 0.99111 \\
\hline $\begin{array}{l}\text { Banking \& } \\
\text { Investment Finance }\end{array}$ & 1.58200 & 16.88140 & 0.59527 \\
\hline Cement & 10.99000 & 17.93000 & 1.49865 \\
\hline $\begin{array}{ll}\text { Construction } & \& \\
\text { Infrastructure } & \\
\end{array}$ & 7.36000 & 18.28000 & 0.54166 \\
\hline $\begin{array}{l}\text { FMCG \& Food \& } \\
\text { Beverages }\end{array}$ & 17.17333 & 42.44000 & 1.77673 \\
\hline $\begin{array}{l}\text { Information } \\
\text { Technology (IT) }\end{array}$ & 19.13600 & 28.32800 & 1.16284 \\
\hline Metals & 7.25333 & 14.57333 & 0.37604 \\
\hline Mining & 22.91333 & 29.26000 & 3.48309 \\
\hline Oil \& Gas & 9.08400 & 14.29200 & 2.10614 \\
\hline Paints & 18.32000 & 37.88000 & 2.21824 \\
\hline Pharmaceuticals & 12.46500 & 18.95000 & 1.30435 \\
\hline Power & 6.42666 & 11.67333 & 4.14648 \\
\hline Telecom & 9.50000 & 14.76000 & 1.90467 \\
\hline \multicolumn{4}{|c|}{ B. Standard Deviation (SD) } \\
\hline & ROA & ROE & $\mathrm{CR}$ \\
\hline Overall & 7.85658 & 14.94132 & 1.59393 \\
\hline Size 1 & 7.43497 & 22.18539 & 0.71726 \\
\hline Size 2 & \begin{tabular}{|l|}
7.90954 \\
\end{tabular} & 8.66573 & 1.37346 \\
\hline Size 3 & 2.94491 & 8.02408 & 2.74390 \\
\hline Size 4 & 3.88461 & 4.74832 & 1.63657 \\
\hline Automobiles & 8.11272 & 18.10613 & 0.87329 \\
\hline $\begin{array}{l}\text { Banking \& } \\
\text { Investment Finance }\end{array}$ & 0.56318 & 3.98699 & 0.94209 \\
\hline Cement & 1.19247 & 1.68432 & 1.02429 \\
\hline $\begin{array}{ll}\text { Construction } & \& \\
\text { Infrastructure } & \\
\end{array}$ & 2.00748 & 9.22524 & 0.38671 \\
\hline $\begin{array}{lll}\text { FMCG \& Food \& } \\
\text { Beverages }\end{array}$ & 10.9066 & 50.65556 & 0.75878 \\
\hline $\begin{array}{l}\text { Information } \\
\text { Technology (IT) }\end{array}$ & 5.14389 & 4.82623 & 0.69614 \\
\hline Metals & 4.44235 & 11.72594 & 0.27090 \\
\hline
\end{tabular}




\begin{tabular}{|c|c|c|c|}
\hline Mining & 9.93815 & 1.25904 & 3.51158 \\
\hline Oil \& Gas & 2.93521 & 4.32882 & 1.51965 \\
\hline Paints & $\mathrm{NA}^{\#}$ & $\mathrm{NA}^{\#}$ & $\mathrm{NA}^{\#}$ \\
\hline Pharmaceuticals & 4.80384 & 6.57132 & 0.47908 \\
\hline Power & 2.11625 & 3.66466 & 3.15586 \\
\hline Telecom & $\mathrm{NA}^{\#}$ & $\mathrm{NA}^{\#}$ & $\mathrm{NA}^{\#}$ \\
\hline \multicolumn{4}{|l|}{ C. Maximum } \\
\hline & ROA & ROE & $\mathrm{CR}$ \\
\hline Overall & 30.14000 & 98.28000 & 7.48339 \\
\hline Size 1 & 30.14000 & 98.28000 & 2.76931 \\
\hline Size 2 & 25.90000 & 36.08000 & 4.17606 \\
\hline Size 3 & 11.58000 & 30.24000 & 7.48339 \\
\hline Size 4 & 11.80000 & 22.88200 & 6.04805 \\
\hline Automobiles & 24.66000 & 52.20000 & 2.54118 \\
\hline $\begin{array}{l}\text { Banking \& } \\
\text { Investment Finance }\end{array}$ & 2.68000 & 22.88200 & 3.12185 \\
\hline Cement & 11.80000 & 19.98000 & 2.76931 \\
\hline $\begin{array}{ll}\text { Construction } & \& \\
\text { Infrastructure } & \\
\end{array}$ & 9.66000 & 26.22000 & 0.91191 \\
\hline $\begin{array}{l}\text { FMCG \& Food \& } \\
\text { Beverages }\end{array}$ & 26.86000 & 98.28000 & 2.24900 \\
\hline $\begin{array}{l}\text { Information } \\
\text { Technology (IT) }\end{array}$ & 25.90000 & 36.08000 & 2.34742 \\
\hline Metals & 12.38000 & 27.94000 & 0.68884 \\
\hline Mining & 30.14000 & 30.24000 & 7.48339 \\
\hline Oil \& Gas & 11.80000 & 19.38000 & 4.17606 \\
\hline Paints & 18.32000 & 37.88000 & 2.21824 \\
\hline Pharmaceuticals & 17.18000 & 26.98000 & 1.89898 \\
\hline Power & 8.78000 & 14.12000 & 6.04805 \\
\hline Telecom & 9.50000 & 14.76000 & 1.90467 \\
\hline \multicolumn{4}{|l|}{ D. Minimum } \\
\hline & ROA & ROE & $\mathrm{CR}$ \\
\hline Overall & 0.95600 & -0.56000 & 0.05438 \\
\hline Size 1 & 5.36000 & -0.56000 & 0.46289 \\
\hline Size 2 & \begin{tabular}{|l|}
1.27000 \\
\end{tabular} & 7.46000 & 0.21731 \\
\hline Size 3 & 1.63200 & 8.16000 & 0.14036 \\
\hline Size 4 & 0.95600 & 6.02000 & 0.05438 \\
\hline Automobiles & 7.56000 & 14.92000 & 0.46289 \\
\hline $\begin{array}{l}\text { Banking } \& \\
\text { Investment Finance }\end{array}$ & 0.95600 & 9.95000 & 0.05438 \\
\hline Cement & 9.22000 & 15.88000 & 0.29075 \\
\hline $\begin{array}{ll}\text { Construction } & \& \\
\text { Infrastructure } & \\
\end{array}$ & 5.96000 & 8.16000 & 0.14036 \\
\hline $\begin{array}{l}\text { FMCG \& Food \& } \\
\text { Beverages }\end{array}$ & 5.36000 & -0.56000 & 0.90148 \\
\hline
\end{tabular}


Dasgupta | Behavioral Implications of Risk-Return Associations CNX NIFTY

\begin{tabular}{|l|l|l|l|}
\hline $\begin{array}{l}\text { Information } \\
\text { Technology (IT) }\end{array}$ & 13.82000 & 24.04000 & 0.52145 \\
\hline Metals & 4.54000 & 6.02000 & 0.21731 \\
\hline Mining & 11.58000 & 27.84000 & 0.90899 \\
\hline Oil \& Gas & 4.76000 & 8.62000 & 0.63367 \\
\hline Paints & 18.32000 & 37.88000 & 2.21824 \\
\hline Pharmaceuticals & 5.78000 & 11.46000 & 0.89933 \\
\hline Power & 4.68000 & 7.46000 & 0.50358 \\
\hline Telecom & 9.50000 & 14.76000 & 1.90467 \\
\hline
\end{tabular}

$\mathrm{NA}^{\#}$ Only 1 company, so can't be calculated

The descriptive statistics of the selected variables for all the CNX NIFTY [i.e., Nifty-50] companies are provided in Table 3. They indicate that the mean of the rate of ROA is about 10.71640 which implies that the average net income of these companies is around $10.72 \%$ of their total assets. Moreover, the mean of the rate of ROE is about $21.78 \%$ (appx.), and the mean of the ratio of capital is about 1.47120 , which shows that on average the Indian companies' capital is about $1.47 \%$ of their total assets. Table 3 also shows how Size and Industry Group companies are contributing towards the overall results. In regard to returns (i.e., both ROA and ROE), Size 1 CNX NIFTY companies are the front-runners in driving the overall results of all such companies. However, their ROE returns are also most risky (higher SD value). But, in terms of ROA returns, Size 1 companies are following their Size 2 counterparts. This shows the normal risk-return relationships (however only in terms of ROE and not ROA) for these companies. In regard to both risk and returns parameter, Size 3 and 4 classified companies are laggards. However, in regard to the $\mathrm{CR}$, it is found that Size 3 companies are more equity-heavy than their other counterparts. The CR is minimum (i.e., 0.99\% [appx.]) for Size 4 companies which imply that big Indian companies are more dependent on debt capital which itself implies their risk-seeking attitude. This is clear from their balance sheets (source: moneycontrol.com). It is due to the fact that higher debt capital in the capital structure of the company implies higher financial risks that the companies are taking knowingly. The Industry groups' results show that mining, IT, paints, FMCG \& food \& beverages and automobiles companies (all are showing above average ROA and ROE) are contributing most in overall returns of the CNX NIFTY companies. However, banking \& investment finance, power, metals, telecom companies are not contributing at par with them. However, these results also indicate the positive risk-return relationships as higher SD values are also associated with higher returns companies. It is also evident that capital intensive industries like power, mining, etc. are more equity-prone than their metals, construction \& infrastructure and banking \& investment finance peers from the Nifty Index.

Table 4: Cross-sectional median values

\begin{tabular}{|c|c|c|c|}
\hline & MEDMROA & MEDMROE & MEDMCR \\
\hline Overall & 9.70000 & 19.21500 & 0.88162 \\
\hline Size 1 & 14.20000 & 24.30000 & 1.46558 \\
\hline Size 2 & 11.40000 & 19.28000 & 1.02106 \\
\hline Size 3 & 5.60000 & 14.50000 & 0.58518 \\
\hline Size 4 & 2.60000 & 17.17000 & 0.28353 \\
\hline Automobiles & 9.70000 & 31.30000 & 0.63527 \\
\hline
\end{tabular}




\begin{tabular}{|c|c|c|c|}
\hline $\begin{array}{c}\text { Banking \& } \\
\text { Investment } \\
\text { Finance }\end{array}$ & 1.53000 & 18.16000 & 0.16850 \\
\hline Cement & 10.50000 & 16.40000 & 1.42201 \\
\hline $\begin{array}{c}\text { Construction \& } \\
\text { Infrastructure }\end{array}$ & 5.60000 & 17.80000 & 0.54965 \\
\hline $\begin{array}{c}\text { FMCG \& Food } \\
\text { \& Beverages }\end{array}$ & 19.30000 & 30.40000 & 2.13007 \\
\hline $\begin{array}{c}\text { Information } \\
\text { Technology (IT) }\end{array}$ & 15.50000 & 24.60000 & 0.99060 \\
\hline Metals & 6.60000 & 12.60000 & 0.22564 \\
\hline Mining & 27.30000 & 33.00000 & 1.89720 \\
\hline Oil \& Gas & 10.30000 & 15.70000 & 1.69194 \\
\hline Paints* & 18.00000 & 36.00000 & 2.07999 \\
\hline Pharmaceuticals & 13.40000 & 21.95000 & 1.21126 \\
\hline Power & 5.80000 & 14.10000 & 5.96133 \\
\hline Telecom* & 5.70000 & 12.40000 & 1.33718 \\
\hline
\end{tabular}

Here, MEDMROA - Overall/Sub Group Median ROA, MEDMROE - Overall/Sub Group Median ROE and MEDMCR - Overall/Sub Group Median CR

Table 4 shows cross-sectional median values which are used as targets for all the CNX NIFTY companies overall and Size and Industry group companies. The cross-sectional median values (i.e., CNX NIFTY companies' [overall] median returns and within sub groups) are based on individual companies' median values overall and under all sub groups.

Table 5: CNX NIFTY [i.e., Nifty-50] companies classifications

\begin{tabular}{|c|c|c|c|}
\hline \multicolumn{4}{|c|}{ A. Overall } \\
\hline & Total & 1-Above Target & 2-Below Target \\
\hline ROA & 50 & 26 & 24 \\
\hline ROE & 50 & 25 & 25 \\
\hline $\mathrm{CR}$ & 50 & 25 & 25 \\
\hline \multicolumn{4}{|c|}{ B. Size } \\
\hline B1. Size 1: & Total & 1-Above Target & 2-Below Target \\
\hline ROA & 17 & 09 & 08 \\
\hline ROE & 17 & 09 & 08 \\
\hline CR & 17 & 09 & 08 \\
\hline B2. Size 2: & Total & 1-Above Target & 2-Below Target \\
\hline ROA & 11 & 06 & 05 \\
\hline ROE & 11 & 06 & 05 \\
\hline $\mathrm{CR}$ & 11 & 06 & 05 \\
\hline B3. Size 3: & Total & 1-Above Target & 2-Below Target \\
\hline ROA & 09 & 05 & 04 \\
\hline ROE & 09 & 05 & 04 \\
\hline $\mathrm{CR}$ & 09 & 05 & 04 \\
\hline B4. Size 4: & Total & 1-Above Target & 2-Below Target \\
\hline ROA & 13 & 07 & 06 \\
\hline ROE & 13 & 07 & 06 \\
\hline $\mathrm{CR}$ & 13 & 07 & 06 \\
\hline \multicolumn{4}{|c|}{ C. Industry } \\
\hline
\end{tabular}


Dasgupta | Behavioral Implications of Risk-Return Associations CNX NIFTY

\begin{tabular}{|c|c|c|c|}
\hline C1. Automobiles: & Total & 1-Above Target & 2-Below Target \\
\hline ROA & 05 & 03 & 02 \\
\hline ROE & 05 & 03 & 02 \\
\hline $\mathrm{CR}$ & 05 & 03 & 02 \\
\hline $\begin{array}{l}\text { C2. Banking \& Investment } \\
\text { Finance: }\end{array}$ & Total & 1-Above Target & 2-Below Target \\
\hline ROA & 10 & 05 & 05 \\
\hline ROE & 10 & 05 & 05 \\
\hline $\mathrm{CR}$ & 10 & 05 & 05 \\
\hline C3. Cement: & Total & 1-Above Target & 2-Below Target \\
\hline ROA & 04 & 02 & 02 \\
\hline ROE & 04 & 02 & 02 \\
\hline $\mathrm{CR}$ & 04 & 02 & 02 \\
\hline $\begin{array}{l}\text { C4. Construction } \quad \& \\
\text { Infrastructure: }\end{array}$ & Total & 1-Above Target & 2-Below Target \\
\hline ROA & 03 & 02 & 01 \\
\hline ROE & 03 & 02 & 01 \\
\hline $\mathrm{CR}$ & 03 & 02 & 01 \\
\hline $\begin{array}{l}\text { C5. FMCG \& Food \& } \\
\text { Beverages: }\end{array}$ & Total & 1-Above Target & 2-Below Target \\
\hline ROA & 03 & 02 & 01 \\
\hline ROE & 03 & 02 & 01 \\
\hline $\mathrm{CR}$ & 03 & 02 & 01 \\
\hline $\begin{array}{l}\text { C6. Information Technology } \\
\text { (IT): }\end{array}$ & Total & 1-Above Target & 2-Below Target \\
\hline ROA & 05 & 03 & 02 \\
\hline ROE & 05 & 03 & 02 \\
\hline $\mathrm{CR}$ & 05 & 03 & 02 \\
\hline C7. Metals: & Total & 1-Above Target & 2-Below Target \\
\hline ROA & 03 & 02 & 01 \\
\hline ROE & 03 & 02 & 01 \\
\hline $\mathrm{CR}$ & 03 & 02 & 01 \\
\hline C8. Mining: & Total & 1-Above Target & 2-Below Target \\
\hline ROA & 03 & 02 & 01 \\
\hline ROE & 03 & 02 & 01 \\
\hline $\mathrm{CR}$ & 03 & 02 & 01 \\
\hline C9. Oil \& Gas: & Total & 1-Above Target & 2-Below Target \\
\hline ROA & 05 & 03 & 02 \\
\hline ROE & 05 & 03 & 02 \\
\hline $\mathrm{CR}$ & 05 & 03 & 02 \\
\hline C10. Paints: & Total & 1-Above Target & 2-Below Target \\
\hline ROA & 01 & \multirow{3}{*}{\multicolumn{2}{|c|}{$\begin{array}{c}\text { Company's median return is equal to Industry's median as } \\
\text { there is only } 1 \text { company }\end{array}$}} \\
\hline ROE & 01 & & \\
\hline $\mathrm{CR}$ & 01 & & \\
\hline C11. Pharmaceuticals: & Total & 1-Above Target & 2-Below Target \\
\hline ROA & 04 & 02 & 02 \\
\hline ROE & 04 & 02 & 02 \\
\hline $\mathrm{CR}$ & 04 & 02 & 02 \\
\hline C12. Power: & Total & 1-Above Target & 2-Below Target \\
\hline ROA & 03 & 02 & 01 \\
\hline ROE & 03 & 02 & 01 \\
\hline $\mathrm{CR}$ & 03 & 02 & 01 \\
\hline C13. Telecom: & Total & 1-Above Target & 2-Below Target \\
\hline ROA & 01 & \multirow{3}{*}{\multicolumn{2}{|c|}{$\begin{array}{c}\text { Company's median return is equal to Industry's median as } \\
\text { there is only } 1 \text { company }\end{array}$}} \\
\hline ROE & 01 & & \\
\hline $\mathrm{CR}$ & 01 & & \\
\hline
\end{tabular}


Table 5 shows the allocation of the CNX NIFTY companies (50 in total) above and below the target returns levels. There are 26 and 24, 25 and 25, and 25 and 25 companies both above and below the target under ROA, ROE and CR respectively. Companies whose median value equal to or exceed the target outcome (i.e., cross-sectional median values) have a classification of 1 , i.e., above-target. Below- target companies have a classification of 2 . Similarly there are 17, 11, 9 and 13 companies as divided based on their respective asset size under Size 1-4, and all 50 companies based on their Sector under 13 industry sub groups. Table 5 also shows the number of companies of different such sub groups under both above and below target returns. Generally, equal representation is found in all the sub groups.

Table 6: Kendall’s correlations results (Overall)

\begin{tabular}{|l|l|l|l|}
\hline & Total & $1-$ Above Target & 2-Below Target \\
\hline ROA & 50 & 0.201 & -0.036 \\
\hline ROE & 50 & -0.073 & -0.041 \\
\hline CR & 50 & $0.400^{* *}$ & $0.560^{* *}$ \\
\hline
\end{tabular}

Kendall $\tau$ correlation coefficients between the standard deviation and the distance to median are shown for each zone, * Correlation is significant at the 0.05 level (2-tailed), ** Correlation is significant at the 0.01 level (2-tailed)

Table 6 provides the Kendall's correlations results for the 50 CNX NIFTY companies. The correlations are not significant above and below target (except CR). Results are also mixed.

The Kendall's coefficients for ROA is positive (in line with Hypothesis 2) and for ROE it is negative (rejects Hypothesis 2) in the correlation results between distance from target and standard deviation for above target outcomes. However, as they are insignificant at $5 \%$ level, these results can't be conclusive. The CR result however accepts Hypothesis 2 for above target companies. Thus, it implies that Indian companies located above target levels in terms of ROA (insignificant but with positive sign [see Fiegenbaum, 1990]) (it implies may be true for few companies in the overall group) and CR significantly exhibit a risk-averse behavior. This also indicates that the Prospect Theory implications holds true for these companies. But, it is a limitation of study results in regard to ROA and ROE and open for future researchers to study on a bigger datasets.

In regard to the relationship between distance from target and standard deviation for below target outcomes, this study finds that Indian companies located below target levels in terms of ROE and ROA (insignificant) are showing negative correlations. This doesn't accept Hypothesis 1 for these companies. Thus, these results don't tend to support the Prospect Theory and Bowman's (1980) risk-return associations among the below-target level companies, and imply that the decision makers are not risk-seeking if they perceive themselves to be operating below the target. However, the $\mathrm{CR}$ of such companies contradicts significantly with the above results. It supports the above theoretical implications. 
Dasgupta| Behavioral Implications of Risk-Return Associations CNX NIFTY

\section{Table 7: Kendall's Correlations Results (Size and Industry Groups)}

\begin{tabular}{|c|c|c|c|}
\hline \multicolumn{4}{|c|}{ A. Size } \\
\hline A1. Size 1: & Total & 1-Above Target & 2-Below Target \\
\hline $\mathrm{ROA}$ & 17 & 0.333 & 0.182 \\
\hline ROE & 17 & 0.222 & 0.000 \\
\hline $\mathrm{CR}$ & 17 & 0.333 & 0.214 \\
\hline A2. Size 2: & Total & 1-Above Target & 2-Below Target \\
\hline ROA & 11 & 0.200 & -0.400 \\
\hline ROE & 11 & 0.200 & -0.600 \\
\hline $\mathrm{CR}$ & 11 & 0.600 & 0.800 \\
\hline A3. Size 3: & Total & 1-Above Target & 2-Below Target \\
\hline ROA & 09 & -0.200 & 0.333 \\
\hline ROE & 09 & -0.400 & 0.667 \\
\hline $\mathrm{CR}$ & 09 & 0.200 & $1.000 *$ \\
\hline A4. Size 4: & Total & 1-Above Target & 2-Below Target \\
\hline ROA & 13 & -0.048 & 0.200 \\
\hline ROE & 13 & $-0.905^{* *}$ & 0.200 \\
\hline $\mathrm{CR}$ & 13 & 0.333 & 0.467 \\
\hline \multicolumn{4}{|c|}{ B. Industry } \\
\hline B1. Automobiles: & Total & 1-Above Target & 2-Below Target \\
\hline ROA & 05 & -0.333 & $-1.000 * *$ \\
\hline ROE & 05 & -0.333 & $1.000 * *$ \\
\hline $\mathrm{CR}$ & 05 & 0.333 & $-1.000 * *$ \\
\hline $\begin{array}{l}\text { B2. Banking \& Investment } \\
\text { Finance: }\end{array}$ & Total & 1-Above Target & 2-Below Target \\
\hline ROA & 10 & -0.200 & -0.200 \\
\hline ROE & 10 & -0.800 & -0.400 \\
\hline $\mathrm{CR}$ & 10 & 0.600 & 0.400 \\
\hline B3. Cement: & Total & 1-Above Target & 2-Below Target \\
\hline ROA & 04 & $-1.000 * *$ & $1.000 * *$ \\
\hline ROE & 04 & $1.000 * *$ & $1.000 * *$ \\
\hline $\mathrm{CR}$ & 04 & $1.000 * *$ & $1.000 * *$ \\
\hline $\begin{array}{l}\text { B4. Construction \& } \\
\text { Infrastructure: }\end{array}$ & Total & 1-Above Target & 2-Below Target \\
\hline ROA & 03 & $1.000 * *$ & $\mathrm{NA}^{\#}$ \\
\hline ROE & 03 & $1.000 * *$ & $\mathrm{NA}^{\#}$ \\
\hline $\mathrm{CR}$ & 03 & $1.000 * *$ & $\mathrm{NA}^{\#}$ \\
\hline $\begin{array}{l}\text { B5. FMCG \& Food \& } \\
\text { Beverages: }\end{array}$ & Total & 1-Above Target & 2-Below Target \\
\hline ROA & 03 & $1.000 * *$ & $\mathrm{NA}^{\#}$ \\
\hline ROE & 03 & $1.000 * *$ & $\mathrm{NA}^{\#}$ \\
\hline $\mathrm{CR}$ & 03 & $-1.000 * *$ & $\mathrm{NA}^{\#}$ \\
\hline $\begin{array}{l}\text { B6. } \\
\text { Technology (IT): }\end{array}$ & Total & 1-Above Target & 2-Below Target \\
\hline ROA & 05 & $1.000 * *$ & $1.000 * *$ \\
\hline ROE & 05 & 0.333 & $1.000 * *$ \\
\hline $\mathrm{CR}$ & 05 & 0.333 & $1.000 * *$ \\
\hline B7. Metals: & Total & 1-Above Target & 2-Below Target \\
\hline $\mathrm{ROA}$ & 03 & $1.000 * *$ & $\mathrm{NA}^{\#}$ \\
\hline ROE & 03 & $-1.000 * *$ & $\mathrm{NA}^{\#}$ \\
\hline $\mathrm{CR}$ & 03 & $1.000 * *$ & $\mathrm{NA}^{\#}$ \\
\hline
\end{tabular}




\begin{tabular}{|c|c|c|c|}
\hline B8. Mining: & Total & 1-Above Target & 2-Below Target \\
\hline ROA & 03 & $1.000^{* *}$ & $\mathrm{NA}^{\#}$ \\
\hline ROE & 03 & $-1.000 * *$ & $\mathrm{NA}^{\#}$ \\
\hline CR & 03 & $1.000 * *$ & $\mathrm{NA}^{\#}$ \\
\hline B9. Oil \& Gas: & Total & 1-Above Target & 2-Below Target \\
\hline $\mathrm{ROA}$ & 05 & -0.333 & $1.000 * *$ \\
\hline $\mathrm{ROE}$ & 05 & -0.333 & $-1.000 * *$ \\
\hline $\mathrm{CR}$ & 05 & 0.333 & $-1.000 * *$ \\
\hline B10. Paints: & Total & 1-Above Target & 2-Below Target \\
\hline ROA & 01 & \multirow{3}{*}{\multicolumn{2}{|c|}{$\begin{array}{l}\text { Only } 1 \text { company. So, no question of above or below } \\
\text { target one. }\end{array}$}} \\
\hline ROE & 01 & & \\
\hline $\mathrm{CR}$ & 01 & & \\
\hline B11. Pharmaceuticals: & Total & 1-Above Target & 2-Below Target \\
\hline ROA & 04 & $1.000 * *$ & $-1.000 * *$ \\
\hline ROE & 04 & $-1.000 * *$ & $1.000 * *$ \\
\hline $\mathrm{CR}$ & 04 & $-1.000 * *$ & $1.000 * *$ \\
\hline B12. Power: & Total & 1-Above Target & 2-Below Target \\
\hline ROA & 03 & $-1.000 * *$ & $\mathrm{NA}^{\#}$ \\
\hline ROE & 03 & $-1.000 * *$ & $\mathrm{NA}^{\#}$ \\
\hline $\mathrm{CR}$ & 03 & $-1.000 * *$ & $\mathrm{NA}^{\#}$ \\
\hline B13. Telecom: & Total & 1-Above Target & 2-Below Target \\
\hline ROA & 01 & \multirow{3}{*}{\multicolumn{2}{|c|}{$\begin{array}{l}\text { Only } 1 \text { company. So, no question of above or below } \\
\text { target one. }\end{array}$}} \\
\hline $\mathrm{ROE}$ & 01 & & \\
\hline CR & 01 & & \\
\hline
\end{tabular}

$\mathrm{NA}^{\#}$ Only 1 company, so no calculation is possible

Kendall $\tau$ correlation coefficients between the standard deviation and the distance to median are shown for each zone, ** Correlation is significant at the 0.01 level (2-tailed) and * Correlation is significant at the 0.05 level (2tailed)

Table 7 provides Kendall's correlations results for Size and Industry sub groups for the 50 CNX NIFTY companies. The results are also not consistent in different sub groups and contradictory in comparison to the overall results. For 17 Size 1 companies, it is found that the above target companies are not accepting Hypothesis 2, which implies that these companies are risk-seeking. Below target companies are however risk-averse, as Hypothesis 1 is rejected under ROA, ROE and CR. The above target Size 2 companies are also risk-averse, also both ROA and ROE of Size 2 below target companies accept Hypothesis 1 which implies that they are risk-seeking. Results of Size 3 and 4 above target companies are also inconclusive in judging managers' risk-seeking behavior as evidenced by insignificant negative ROA. However, in case of ROE of Size 4 companies, the result is very significant. So, Hypothesis 2 is rejected mainly in Size 4 companies. It implies that those above target companies' managers are risk-seeking in nature. However, Size 3 below target companies' CR results significantly reject Hypothesis 1 and thereby implies that the Prospect Theory implication that managers of below target companies are risk-seeking are not true for this set of Indian companies.

In case of industry sub group companies, the automobiles, banking $\&$ investment finance and oil $\&$ gas above target companies show negative sign correlations in returns. However, these results are not significant. It may be implied that few of these industry sub-group companies are riskseeking in attitude (see Fiegenbaum, 1990). However, the CR of all these companies shows contradictory results. The below target companies under automobiles and oil \& gas industry sub 
groups significantly accept Hypothesis 1 on most of the selected parameters (except ROE in automobiles and ROA in oil \& gas). This indicates their risk-seeking attitude. However, it is seen here that the below target companies under cement and IT (with significant positive correlations), and pharmaceuticals (except ROA) reject Hypothesis 1. Thus, all these companies are risk-averse in nature. The above target companies under cement (except ROA) and IT (significant in ROA) however accept Hypothesis 2 which also evidences their risk-averse nature. But, above target pharmaceuticals companies except ROA reject Hypothesis 2 which indicates their risk-seeking behavior. The above target construction \& infrastructure companies have significant positive correlations under all measures which also show the presence of the Prospect Theory implications and risk-return paradox in their attitude. The results also show that FMCG $\&$ food \& beverages (except CR), metals and mining (except ROE all are showing significant positive correlations) above target companies all accept Hypothesis 2 which is indicative of their managers' risk-averse attitude. In case of power industry group also, all selected measures of above target companies reject Hypothesis 2. This is evident of their risk-seeking attitude.

Thus, it can be concluded here that some (size-to-size and industry-to-industry basis) of the Nifty-50 Indian companies under both below and above target levels, show the presence of the Prospect Theory implications and Bowman's $(1980 ; 1982)$ risk-return paradox (see Table 8).

Table 8: Summary of Risk Attitude Results

\begin{tabular}{|c|c|c|c|c|c|c|}
\hline \multirow{2}{*}{ Groups } & \multicolumn{3}{|c|}{ Above Target } & \multicolumn{3}{|c|}{ Below Target } \\
\hline & ROA & ROE & $\mathrm{CR}$ & ROA & ROE & $\mathrm{CR}$ \\
\hline Overall & $\begin{array}{l}\text { Risk averse } \\
\text { (Inconclusive) }\end{array}$ & $\begin{array}{l}\text { Risk seeking } \\
\text { (Inconclusive) }\end{array}$ & $\begin{array}{l}\text { Risk averse } \\
\text { (Significant) }\end{array}$ & $\begin{array}{l}\text { Risk seeking } \\
\text { (Inconclusive) }\end{array}$ & $\begin{array}{l}\text { Risk averse } \\
\text { (Inconclusive) }\end{array}$ & $\begin{array}{l}\text { Risk seeking } \\
\text { (Significant) }\end{array}$ \\
\hline Size 1 & $\begin{array}{l}\text { Risk averse } \\
\text { (Inconclusive) }\end{array}$ & $\begin{array}{l}\text { Risk averse } \\
\text { (Inconclusive) }\end{array}$ & $\begin{array}{l}\text { Risk averse } \\
\text { (Inconclusive) }\end{array}$ & $\begin{array}{l}\text { Risk averse } \\
\text { (Inconclusive) }\end{array}$ & $\begin{array}{l}\text { Risk averse } \\
\text { (Inconclusive) }\end{array}$ & $\begin{array}{l}\text { Risk averse } \\
\text { (Inconclusive) }\end{array}$ \\
\hline Size 2 & $\begin{array}{l}\text { Risk averse } \\
\text { (Inconclusive) }\end{array}$ & $\begin{array}{l}\text { Risk averse } \\
\text { (Inconclusive) }\end{array}$ & $\begin{array}{l}\text { Risk averse } \\
\text { (Inconclusive) }\end{array}$ & $\begin{array}{l}\text { Risk seeking } \\
\text { (Inconclusive) }\end{array}$ & $\begin{array}{l}\text { Risk seeking } \\
\text { (Inconclusive) }\end{array}$ & $\begin{array}{l}\text { Risk averse } \\
\text { (Inconclusive) }\end{array}$ \\
\hline Size 3 & $\begin{array}{l}\text { Risk seeking } \\
\text { (Inconclusive) }\end{array}$ & $\begin{array}{l}\text { Risk seeking } \\
\text { (Inconclusive) }\end{array}$ & $\begin{array}{l}\text { Risk averse } \\
\text { (Inconclusive) }\end{array}$ & $\begin{array}{l}\text { Risk averse } \\
\text { (Inconclusive) }\end{array}$ & $\begin{array}{l}\text { Risk averse } \\
\text { (Inconclusive) }\end{array}$ & $\begin{array}{l}\text { Risk averse } \\
\text { (Significant) }\end{array}$ \\
\hline Size 4 & $\begin{array}{l}\text { Risk seeking } \\
\text { (Inconclusive) }\end{array}$ & $\begin{array}{l}\text { Risk seeking } \\
\text { (Significant) }\end{array}$ & $\begin{array}{l}\text { Risk averse } \\
\text { (Inconclusive) }\end{array}$ & $\begin{array}{l}\text { Risk averse } \\
\text { (Inconclusive) }\end{array}$ & $\begin{array}{l}\text { Risk averse } \\
\text { (Inconclusive) }\end{array}$ & $\begin{array}{l}\text { Risk averse } \\
\text { (Inconclusive) }\end{array}$ \\
\hline Automobiles & $\begin{array}{l}\text { Risk seeking } \\
\text { (Inconclusive) }\end{array}$ & $\begin{array}{l}\text { Risk seeking } \\
\text { (Inconclusive) }\end{array}$ & $\begin{array}{l}\text { Risk averse } \\
\text { (Inconclusive) }\end{array}$ & $\begin{array}{l}\text { Risk seeking } \\
\text { (Significant) }\end{array}$ & $\begin{array}{l}\text { Risk averse } \\
\text { (Significant) }\end{array}$ & $\begin{array}{l}\text { Risk seeking } \\
\text { (Significant) }\end{array}$ \\
\hline $\begin{array}{c}\text { Banking \& } \\
\text { Investment } \\
\text { Finance }\end{array}$ & $\begin{array}{l}\text { Risk seeking } \\
\text { (Inconclusive) }\end{array}$ & $\begin{array}{l}\text { Risk seeking } \\
\text { (Inconclusive) }\end{array}$ & $\begin{array}{l}\text { Risk averse } \\
\text { (Inconclusive) }\end{array}$ & $\begin{array}{l}\text { Risk seeking } \\
\text { (Inconclusive) }\end{array}$ & $\begin{array}{l}\text { Risk seeking } \\
\text { (Inconclusive) }\end{array}$ & $\begin{array}{l}\text { Risk averse } \\
\text { (Inconclusive) }\end{array}$ \\
\hline Cement & $\begin{array}{l}\text { Risk seeking } \\
\text { (Significant) }\end{array}$ & $\begin{array}{l}\text { Risk averse } \\
\text { (Inconclusive) }\end{array}$ & $\begin{array}{l}\text { Risk averse } \\
\text { (Inconclusive) }\end{array}$ & $\begin{array}{l}\text { Risk averse } \\
\text { (Significant) }\end{array}$ & $\begin{array}{l}\text { Risk averse } \\
\text { (Significant) }\end{array}$ & $\begin{array}{l}\text { Risk averse } \\
\text { (Significant) }\end{array}$ \\
\hline $\begin{array}{c}\text { Construction } \\
\& \\
\text { Infrastructure }\end{array}$ & $\begin{array}{l}\text { Risk averse } \\
\text { (Significant) }\end{array}$ & $\begin{array}{l}\text { Risk averse } \\
\text { (Significant) }\end{array}$ & $\begin{array}{l}\text { Risk averse } \\
\text { (Significant) }\end{array}$ & N/A & N/A & N/A \\
\hline $\begin{array}{l}\text { FMCG \& } \\
\text { Food and } \\
\text { Beverages }\end{array}$ & $\begin{array}{l}\text { Risk averse } \\
\text { (Significant) }\end{array}$ & $\begin{array}{l}\text { Risk averse } \\
\text { (Significant) }\end{array}$ & $\begin{array}{l}\text { Risk seeking } \\
\text { (Significant) }\end{array}$ & $\mathrm{N} / \mathrm{A}$ & $\mathrm{N} / \mathrm{A}$ & $\mathrm{N} / \mathrm{A}$ \\
\hline $\begin{array}{c}\text { Information } \\
\text { Technology } \\
\text { (IT) }\end{array}$ & $\begin{array}{l}\text { Risk averse } \\
\text { (Significant) }\end{array}$ & $\begin{array}{l}\text { Risk averse } \\
\text { (Inconclusive) }\end{array}$ & $\begin{array}{l}\text { Risk averse } \\
\text { (Inconclusive) }\end{array}$ & $\begin{array}{l}\text { Risk averse } \\
\text { (Significant) }\end{array}$ & $\begin{array}{l}\text { Risk averse } \\
\text { (Significant) }\end{array}$ & $\begin{array}{l}\text { Risk averse } \\
\text { (Significant) }\end{array}$ \\
\hline Metals & $\begin{array}{l}\text { Risk averse } \\
\text { (Significant) }\end{array}$ & $\begin{array}{l}\text { Risk seeking } \\
\text { (Significant) }\end{array}$ & $\begin{array}{l}\text { Risk averse } \\
\text { (Significant) }\end{array}$ & N/A & $\mathrm{N} / \mathrm{A}$ & N/A \\
\hline Mining & Risk averse & Risk seeking & Risk averse & $\mathrm{N} / \mathrm{A}$ & $\mathrm{N} / \mathrm{A}$ & N/A \\
\hline
\end{tabular}




\begin{tabular}{|c|l|l|l|l|l|l|}
\hline & (Significant) & (Significant) & (Significant) & & & \\
\hline Oil \& Gas & $\begin{array}{l}\text { Risk seeking } \\
\text { (Inconclusive) }\end{array}$ & $\begin{array}{l}\text { Risk seeking } \\
\text { (Inconclusive) }\end{array}$ & $\begin{array}{l}\text { Risk averse } \\
\text { (Inconclusive) }\end{array}$ & $\begin{array}{l}\text { Risk averse } \\
\text { (Significant) }\end{array}$ & $\begin{array}{l}\text { Risk seeking } \\
\text { (Significant) }\end{array}$ & $\begin{array}{l}\text { Risk seeking } \\
\text { (Significant) }\end{array}$ \\
\hline Paints & N/A & N/A & N/A & N/A & N/A \\
\hline Pharmaceuticals & $\begin{array}{l}\text { Risk averse } \\
\text { (Significant) }\end{array}$ & $\begin{array}{l}\text { Risk seeking } \\
\text { (Significant) }\end{array}$ & $\begin{array}{l}\text { Risk seeking } \\
\text { (Significant) }\end{array}$ & $\begin{array}{l}\text { Risk seeking } \\
\text { (Significant) }\end{array}$ & $\begin{array}{l}\text { Risk averse } \\
\text { (Significant) }\end{array}$ & $\begin{array}{l}\text { Risk averse } \\
\text { (Significant) }\end{array}$ \\
\hline Power & $\begin{array}{l}\text { Risk seeking } \\
\text { (Significant) }\end{array}$ & $\begin{array}{l}\text { Risk seeking } \\
\text { (Significant) }\end{array}$ & $\begin{array}{l}\text { Risk seeking } \\
\text { (Significant) }\end{array}$ & N/A & N/A & N/A \\
\hline Telecom & N/A & N/A & N/A & N/A & N/A & N/A \\
\hline
\end{tabular}

\section{Conclusion:}

This study is based on Bowman's $(1980 ; 1982)$ risk-return paradox. According to his findings efficient corporate managers can increase return (represented by ROA and ROE here) and reduce risk simultaneously. So, this is against the normal risk-return positive correlation concept. However, in light of the behavioural decisions of those corporate managers in regard to their risk-attitudes, a target return level or reference point is needed. This study has used the reference point in light of the Prospect Theory framework of Kahneman and Tversky (1979). It is hypothesized that firms and their managers above the target return level (i.e., the reference point, represented by group median returns) are risk-averse and they are risk-seeking when their companies are below that reference point.

It is also a known fact that computation of ROA is done to find the efficiency and ability of the management to use companies' assets. The ROE is a measure which the shareholders look at to judge whether a company and its managers are using their funds most effectively. The ROE is also dependent on the ROA of a company (under Du Pont Analysis). The ETA measure also points out the leverage position of the companies and risk-attitude of their managers. So, ROA and ROE are profitability measures and dependent on managerial decision-making abilities inclusive of risk attitude and ETA which itself is evidential of their risk approach. The model used in this study [i.e., Fishburn's (1977) measure of risk and Kendall's (1938) correlations] also finds out the decision-makers' risk attitude being the representatives of their respective companies.

In regard to returns (i.e., both ROA and ROE), Size 1 CNX NIFTY companies are the frontrunners in driving the overall results. However, their ROE returns are also most risky (higher SD value). If both risk and returns parameters are considered, Size 3 and 4 classified companies are laggards. However, in regard to the CR, it is found that Size 3 companies are more equity-heavy than their other counterparts. The CR is minimum for Size 4 companies which imply that big Indian companies are more dependent on debt capital which itself implies their risk-seeking attitude. The Industry groups' results show that mining, IT, paints, FMCG \& food \& beverages and automobiles companies (all are showing above average ROA and ROE) are contributing most in overall returns of the CNX NIFTY companies. It is also evident that capital intensive industries like power, mining, etc. are more equity-prone than their metals, construction \& infrastructure and banking $\&$ investment finance peers from the Nifty Index.

Generally, the Kendall's correlations are not significant above and below target (except CR) Nifty companies. However, this may be implied from the study results that Indian companies 
located above target levels in terms of significant CR and ROA (through positive correlation coefficient sign) (see Fiegenbaum, 1990) exhibit a risk-averse behavior. It indicates that the Prospect Theory implications holds true for number of these companies.

In regard to the relationship between distance from target and standard deviation for below target outcomes, this study finds that Indian companies located below target levels in terms of ROE and ROA are showing insignificant negative correlations coefficients. This doesn't accept Hypothesis 1 for these companies. These results thereby doesn't tend to support the Prospect Theory and Bowman's (1980) risk-return associations among the below-target level companies, and imply that the decision makers are risk-averse if they perceive themselves to be operating below the target. However, the CR of such companies contradicts significantly with the above results.

The results of Size and Industry sub groups for the 50 CNX NIFTY companies are also not consistent, rather contradictory in different sub groups and in comparison to the overall results. Size 1 and 2 above target companies are risk-seeking whereas Size 3 and 4 above target companies are mostly inconclusive in judging managers' risk-seeking behaviour except in regard to ROE for Size 4 companies which only points out their risk-seeking attitude. In case of industry sub group companies, the automobiles, banking \& investment finance and oil \& gas above target companies show negative correlations in returns which doesn't clearly imply that these companies are risk-seeking in attitude. However, the CR of all these companies shows contradictory results and is evidential of Prospect Theory implications in terms of risk-return paradox. It is also evident that the below target companies under cement and IT (with significant positive correlations) and pharmaceuticals (except ROA) and above target companies under cement (except ROA) and IT (significant in ROA) are risk-averse in nature. The above target construction \& infrastructure companies have significant positive correlations under all measures which also show the presence of the Prospect Theory implications and risk-return paradox in their attitude. The results point out that FMCG \& food \& beverages (except CR), metals and mining (except ROE all are showing significant positive correlations) above target companies all are risk averse.

So, it is quite obvious that determination of Indian managers' risk-attitudes overall for the top Indian companies, size-wise and industry-wise from the Prospect Theory perspective do have implications for the current and prospective investors in these companies. From a practical perspective, the investors will be better prepared to monitor and predict the market performance of their stocks or prospective stock-investments if they understand that Indian managers may become less risk-averse (rather risk-prone) when they operate below-target and that this tendency increases as gain domains start to decline. If investors are aware of these relationships, their predictive stock selections will be more effective, thus ensuring more profitable investments in the future in the Nifty Index or industry-specific choices.

Although this study is based on ex-post accounting data such as the ROA, ROE, etc. of the CNX NIFTY companies, but future studies can take into consideration market based measures to incorporate expectations or can use a questionnaire-based test approach to examine the Prospect Theory implications among these Indian companies. Also, many results are inconclusive (see 
Table 8) which imply that future studies should undertake large indices from the Indian stock markets.

However, the empirical findings under this study provide support for prospect theory applications in judging risk-return paradox and implied associations in between them as reported by many researchers throughout the world. This study also clearly indicates the risk-attitude of the top Indian companies' managers in earning their returns.

Note 1) The CNX Nifty is a well diversified 50 stock index accounting for 13 sectors of the economy. It is used for a variety of purposes such as benchmarking fund portfolios, index based derivatives and index funds (www.nseindia.com).

\section{References:}

Alam, N. and Boon Tang, K. (2012), "Risk-taking behaviour of Islamic banks: application of prospect theory", Qualitative Research in Financial Markets, Vol. 4, No. 2/3, pp. 156 164. https://doi.org/10.1108/17554171211252493

Bajpai, N. (2011). "Global Financial Crisis, its Impact on India and the Policy Response", Working Paper No. 5, Columbia Global Centers, South Asia, Columbia University, pp. $1-13$.

Blair, R.D. and Heggestad, A.A. (1978), "Bank Portfolio Regulation and the Probability of Bank Failure”, A Note. Journal of Money, Credit and Banking, Vol. 10, pp. 88-93. https://doi.org/10.2307/1991474

Brewer, E. III and Lee, C.F. (1986), "How the Market Judges Bank Risk", Economic Perspectives (Federal Reserve Bank of Chicago), Vol. 10, pp. 25-31.

Bowman, E.H. (1980), “A risk/return paradox for strategic management", Sloan Management Review, Vol. 21, pp. 17-31.

Bowman, E.H. (1982), "Risk seeking by troubled firms", Sloan Management Review, Vol. 23, pp. 33-42.

Brumagim, A.L. and Wu, X. (2005). "An examination of cross-cultural differences in attitudes towards risk: testing prospect theory in the People's Republic of China", Multinational Business Review, Vol. 13, pp. 67-86. https://doi.org/10.1108/1525383X200500015

Cheng, C-H. (2010). "Are the Chinese Really More Risk Averse? A Cross-Cultural Comparison of the Risk-Return Relationship", Working Paper, Department of MIS, Kang-Ning Junior College of Medical Care and Management, Taiwan, pp. 1-6.

Chou, P.H., Chou, R.K. and Ko, K.C. (2009). "Prospect theory and the risk-return paradox: some recent evidence", Quantitative Financial Accounting, Vol. 33, pp. 193-208. https://doi.org/10.1007/s11156-009-0109-z

Dasgupta, R. (2013). "India's Integration and Dynamic Linkages with World Emerging Economies and the US - Opportunities for Portfolio Diversification", International Research Journal of Finance and Economics, Issue 117, pp. 225-245.

Davis, J.L. (1996). "The cross-section of returns and survivorship bias: evidence from delisted stocks", Quarterly Reviews of Economic Finance, Vol. 36, pp. 365-375. https://doi.org/10.1016/S1062-9769(96)90021-6

Deephouse, D.L. and Wiseman, R.M. (2000). "Comparing alternative explanations for accounting risk-return relations", Journal of Economic Behavior and Organization, Vol. 42, pp. 463-482. https://doi.org/10.1016/S0167-2681(00)00100-1 
Fiegenbaum, A. (1990), "Prospect Theory and the Risk-Return Association - An Empirical Examination in 85 Industries", Journal of Economic Behaviour and Organisation, Vol. 14, pp. 187-203. https://doi.org/10.1016/0167-2681(90)90074-N

Fiegenbaum, A. and Thomas, H. (1988), "Attitudes toward risk and the risk-return paradox prospect theory explanations”, Academy of Management Journal, Vol. 73, pp. 337-363. https://doi.org/10.2307/256499

Fishburn, P.C. (1977), "Mean-Risk Analysis with Risk Associated with Below-Target Returns", American Economic Review, Vol. 67, pp. 116-126.

Frecka, T.J. and Lee, C.F. (1983), "Generalized Financial Ratio Adjustment Processes and Their Implications", Journal of Accounting Research, Vol. 21, pp. 308-316. https://doi.org/10.2307/2490952

Gokay, B. (2009). "The 2008 World Economic Crisis: Global Shifts and Faultlines", Global Research, $15^{\text {th }}$ February. [Accessed from www.globalresearch.ca on $3^{\text {rd }}$ August, 2013]

Goldstein, M. and Xie, D. (2011). "The Impact of the Financial Crisis on Emerging Asia", Asia Economic Policy Conference, pp. 27-80.

Hart, O.D. and Jaffee, D.M. (1974), "On the Application of Portfolio Theory to Depository Financial Intermediaries", Review of Economic Studies, Vol. 41, pp. 129-147. https://doi.org/10.2307/2296404

International Monetary Fund. (1990), "Recent Developments in Financial Regulation and Market Structures", International Capital Markets: Developments and Prospects, Washington D.C., pp. 43-51.

Jegers, M. (1991), "Prospect theory and the risk-return relation: Some Belgian evidence", Academy of Management Journal, Vol. 34, pp. 215-225. https://doi.org/10.2307/256309

Johnson, H.J. (1994), "Prospect theory in the commercial banking industry", Journal of Financial and Strategic Decisions, Vol. 7, pp. 73-89.

Kahneman, D. and Tversky, A. (1979), "Prospect theory: An analysis of decision under risk", Econometrica, Vol. 47, pp. 263-291. https://doi.org/10.2307/1914185

Kendall, M. (1938), “A New Measure of Rank Correlation”, Biometrika, Vol. 30 Nos. 1-2, pp. 81-89. [Available at: doi:10.1093/biomet/30.1-2.81. JSTOR 2332226]

https://doi.org/10.1093/biomet/30.1-2.81

Kliger, D. and Tsur, I. (2011), "Prospect Theory and Risk-Seeking Behavior by Troubled Firms", Journal of Behavioral Finance, Vol. 12, No. 1, pp. 29-40. https://doi.org/10.1080/15427560.2011.555028

Koehn, M. and Santomero, A.M. (1980), "Regulation of Bank Capital and Portfolio Risk", Journal of Finance, Vol. 35, pp. 1235-1244. https://doi.org/10.1111/j.1540-6261.1980.tb02206.x

La Porta, R., Lopez-de-Silanes, F., Shleifer, A. and Vishny, R.W. (2000). "Investor protection and corporate governance", Journal of Financial Economics, Vol. 58, pp. 3-27. https://doi.org/10.1016/S0304-405X(00)00065-9

Lev, B. (1969), "Industry Averages as Targets for Financial Ratios", Journal of Accounting Research, Vol. 7, pp. 290-299. https://doi.org/10.2307/2489971

Miller, K.D. and Leiblein, M.J. (1996). "Corporate Risk-Return Relations: Returns Variability versus Downside Risk", The Academy of Management Journal, Vol. 39, No. 1, pp. 91122. https://doi.org/10.2307/256632

Nickel, M.N. and Rodrýguez, M.C. (2002). "A review of research on the negative accounting relationship between risk and return: Bowman's paradox", Omega, Vol. 30, pp. 1-18. https://doi.org/10.1016/S0305-0483(01)00055-X 
AABFJ | Volume 11, no. 3, 2017

Securities and Exchange Board of India. (2013), SEBI Annual Report 2012-13.

Securities and Exchange Board of India. (2014), SEBI Annual Report 2013-14.

Tversky, A. and Kahneman, D. (1992), "Advances in Prospect Theory: Cumulative Representation of Uncertainty", Journal of Risk and Uncertainty, Vol. 5, pp. 297-323. https://doi.org/10.1007/BF00122574

www.nseindia.com/content/indices/ind_cnx_nifty.pdf 